\title{
A guide to the identification of subfossil non-chydorid Cladocera (Crustacea: Branchiopoda) from lake sediments of Central America and the Yucatan Peninsula, Mexico: part I
}

\author{
M. Wojewódka $(1) \cdot$ A. Y. Sinev $\cdot$ E. Zawisza
}

Received: 29 August 2018/Accepted: 4 February 2020/Published online: 14 February 2020

(C) The Author(s) 2020

\begin{abstract}
Cladocera (Crustacea: Branchiopoda) quickly respond to changes in environmental conditions and their remains are usually found in large amounts in lacustrine sediments, which make them an important biological proxy in paleolimnological studies. Variations in species composition have been used to infer paleo-climate and paleo-environmental variables including lake depth, eutrophication, and deforestation. However, despite their advantages as bioindicators in the study of past conditions, they are underutilized in paleolimnological research in Central America due to limited knowledge about their diversity and the morphological differences between the subfossil remains of different taxa. In order to address
\end{abstract}

Electronic supplementary material The online version of this article (https://doi.org/10.1007/s10933-020-00115-3) contains supplementary material, which is available to authorized users.

M. Wojewódka $(\bowtie) \cdot$ E. Zawisza

Institute of Geological Sciences, Research Centre in Warsaw, Polish Academy of Sciences, Twarda 51/55, 00818 Warsaw, Poland

e-mail: m.wojed@twarda.pan.pl

\section{A. Y. Sinev}

Department of Invertebrate Zoology, Biological Faculty, Lomonosov Moscow State University, Leninskie Gory, Moscow, Russia 119991

\section{A. Y. Sinev}

Kazan Federal University, Kremlevskaya 18, Kazan, Russia 420008 this issue, we described and analyzed cladoceran remains from 56 waterbodies located in Mexico, Guatemala, El Salvador, and Honduras. Here, we provide a description of the remains from 10 different taxa that belong to the Sididae, Bosminidae, Daphniidae, Macrothricidae, and Ilyocryptidae families.

Keywords Non-chydorid Cladocera $\cdot$ Subfossil remains · Guide · Paleolimnology · Central America · Yucatan Peninsula

\section{Introduction}

Lacustrine sediments provide rich paleoarchives of both floral and faunal remains. Some of the most frequently recorded faunal remains are from Cladocera (Korhola and Rautio 2001). These tiny invertebrates are very important components of zooplankton (Korhola and Rautio 2001; Szeroczyńska and Sarmaja-Korjonen 2007), and play a crucial role in maintaining the balance of aquatic ecosystems. Therefore, they are widely used as a source of information about various environmental events in paleolimnological research. Data on subfossil Cladocera allow inferences to be made on $\mathrm{pH}$, trophic state, and water level change (Korhola and Rautio 2001).

The majority of identification guides deal with recent and intact Cladocera (Flössner 2000; Elías- 
Gutiérrez et al. 2008), and thus their application to subfossil remains is limited (Korosi and Smol 2012a). To recognize living animals, however, the characteristics of soft tissues are also considered. These soft parts of the body decompose after death, and therefore exoskeletons of Cladocera in lacustrine sediments are found as detached body parts such as valves, head shields, and postabdomens (Szeroczyńska and Sarmaja-Korjonen 2007). The existing guides of identification for subfossil cladoceran remains have focused on remains found in North America (Korosi and Smol 2012a, b), central and northern Europe (Szeroczyńska and Sarmaja-Korjonen 2007), and Alaska (Sweetman and Smol 2006). There is more limited literature for cladoceran remains found in Central and South America, as up to recently, only a single paper from Ecuador has been published (López-Blanco and Sinev 2016).

There has been an increasing interest in involving Cladocera in paleoreconstructions of climate and environmental changes in the Neotropical zone (Zawisza et al. 2012, 2017; Cuna et al. 2014; Szeroczyńska et al. 2015). However, current knowledge on the cladoceran communities of this area is limited. Some studies on ecology (Pérez et al. 2013; Wojewódka et al. 2016; Sigal et al. 2017), distribution (ElíasGutiérrez et al. 2006, 2008; Pérez et al. 2013; Wojewódka et al. 2016) and taxonomy (ElíasGutiérrez et al. 1999, 2006, 2008; Sinev and SilvaBriano 2012; Sinev and Zawisza 2013) were conducted; nevertheless, detailed depictions of cladoceran remains are scarce. Thus, there is a need to investigate and describe the ecology and taxonomy of the Central American species. Here we present illustrations and descriptions of the remains of 10 non-chydorid taxa from the Sididae, Bosminidae, Daphniidae, Macrothricidae, and Ilyocryptidae families recovered from 56 waterbodies in Central America and the Yucatan Peninsula.

Remains from the Bosminidae family are usually well preserved in lacustrine sediment and are often the most abundant family, whereas remains from the Sididae, Daphniidae, Macrothricidae and Ilyocryptidae families are usually poorly preserved and found only rarely in lacustrine sediments (Korosi and Smol 2012a). However, remains from all these families are valuable bioindicators, and it is useful to identify and interpret them in paleolimnological studies. Towards this goal, this manual will be useful for both paleo and modern limnological studies.

\section{Materials and methods}

Subfossil Cladocera remains were collected from surface sediment samples and lake sediment cores in 56 waterbodies located in Mexico, Guatemala, El Salvador, and Honduras (Fig. 1, ESM1). These waterbodies were mainly lakes varying in depth, but there were also cenotes and smaller ponds. Most of the studied waterbodies have already been the subject of studies of various limnological characteristics (Pérez et al. 2011), bioindicators such as ostracods, chironomids, and cladocerans together (Pérez et al. 2013), as well as the diversity and distribution of pollen (CorreaMetrio et al. 2011; Franco-Gaviria et al. 2018a), cladocerans (Wojewódka et al. 2016), ostracods (Cohuo et al. 2016), and chironomids (Hamerlik et al. 2018). Additionally, the DNA of the ostracods has been analyzed (Macario-Gonzáleza et al. 2018), along with some paleolimnological studies (Curtis et al. 1998; Escobar et al. 2012; Diaz et al. 2017; Franco-Gaviria et al. 2018b) having been conducted.

For this paper, Cladocera description and analysis was conducted according to the standard methodology (Frey 1986; Szeroczyńska and Sarmaja-Korjonen 2007). Fresh sediment samples $\left(2 \mathrm{~cm}^{3}\right)$ were taken and digested in $10 \% \mathrm{KOH}$ solution. Samples were then stirred with a magnetic stirrer in order to eliminate the humic matter and treated with $10 \% \mathrm{HCl}$ to remove carbonates. Finally, samples were flushed with distilled water and sieved through a $38 \mu \mathrm{m}$ sieve. Thereafter, the residue was transferred to a test tube that was then filled with $5 \mathrm{ml}$ or $10 \mathrm{ml}$ of distilled water. The samples were stained with two drops of safranin. For identification, between three to five slides $\left(0.1 \mathrm{~cm}^{3}\right)$ were examined under an Olympus microscope (equipped with 100-400 $\times$ magnification). Microphotographs were taken using cellSens Standard software. Taxonomic identification was established based on Paggi (1979), Korovchinsky (1992), de Melo and Hebert (1994), Korovchinsky and Elías-Gutiérrez (2000), Hollwedel et al. (2003) and Elías-Gutiérrez et al. (2008), and other relevant literature listed for each cladoceran taxon described below. 


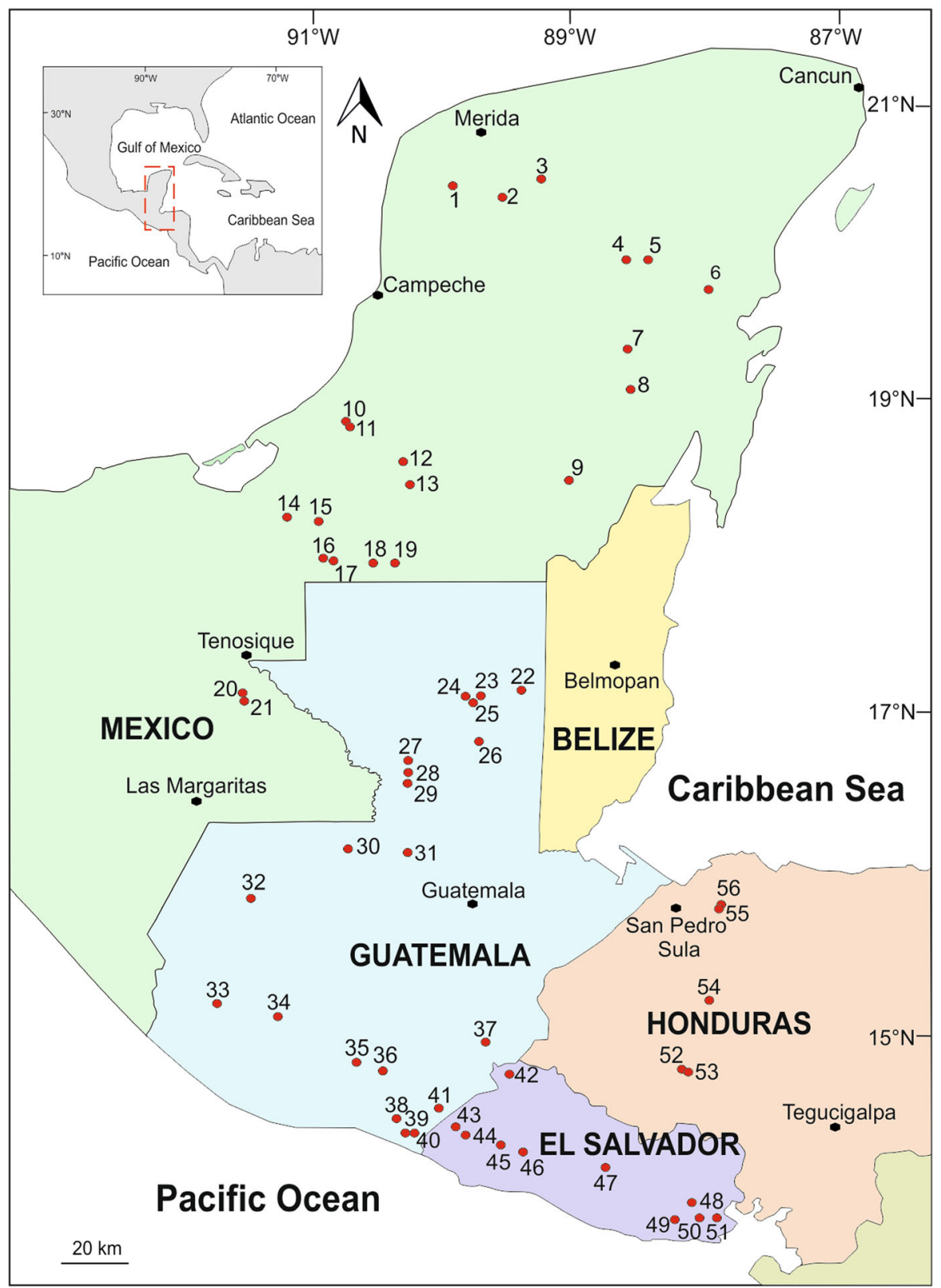

Fig. 1 Map of the study area showing the location of lakes sampled, i.e., Mexico, Guatemala, Honduras and El Salvador. Numbers indicate the names of the waterbodies. Mexico: 1. Cenote Xbatún; 2. Cenote Yumku; 3. Cenote Oxola; 4. Cenote Sacalaca; 5. Sarteneja Dzonot Chel; 6. Lake Señor; 7. Lake Kaná; 8. Lake Emiliano Zapata; 9. Lake San Jose de la Montaña; 10. Lake Xbacab; 11. Lake Chuina; 12. Lake Silvituc; 13. Lake Chan; 14. Rio Salto Grande; 15. Rio Candelaria; 16. Lake Camp; 17. Lake Estado de México; 18. Lake Perdida; 19. Lake Misteriosa; 20. San Lorenzo; 21. Balamtetic; Guatemala: 22. Lake Sacnab; 23. Lake Salpetén; 24. Petén Itza; 25. Lake
Quexil; 26. Lake Oquevix; 27. Lake El Rosario; 28. Lake Petexbatún; 29. Lake Las Pozas; 30. Lake Lachuá; 31. Lake Sepalau; 32. Lake Magdalena; 33. Lake Chicabal; 34. Lake Atitlán; 35. Lake Calderas; 36. Lake El Pino; 37. Lake Ipala; 38. Lake Comandador; 39. Lake El Muchacho; 40. Lake Grande; 41. Lake San Juan Bautista; El Salvador: 42. Lake Metapan; 43. Lake El Espino; 44. Lake Verde; 45. Lake Coatepeque; 46. Lake Chanmico; 47. Lake Apastepeque; 48. Lake Aramuaca; 49. Lake Jocotal; 50. Lake Olomega; 51.Lake Los Negritos; Honduras: 52. Lake Chiligatoro; 53. Lake Madre Vieja; 54. Lake Yojoa; 55. Lake Jucutuma; 56. Lake Ticamaya 


\section{Description of subfossil remains}

Order Ctenopoda Sars, 1865.

Family Sididae Sars, 1865.

\section{Large species.}

The remains of Sididae are susceptible to decomposition, and are usually poorly preserved in sediment. The only part of the animal frequently retained is the post-abdominal claw, which can be identified to the genus level or, sometimes, species level (Szeroczyńska and Sarmaja-Korjonen 2007). The exopodite segment
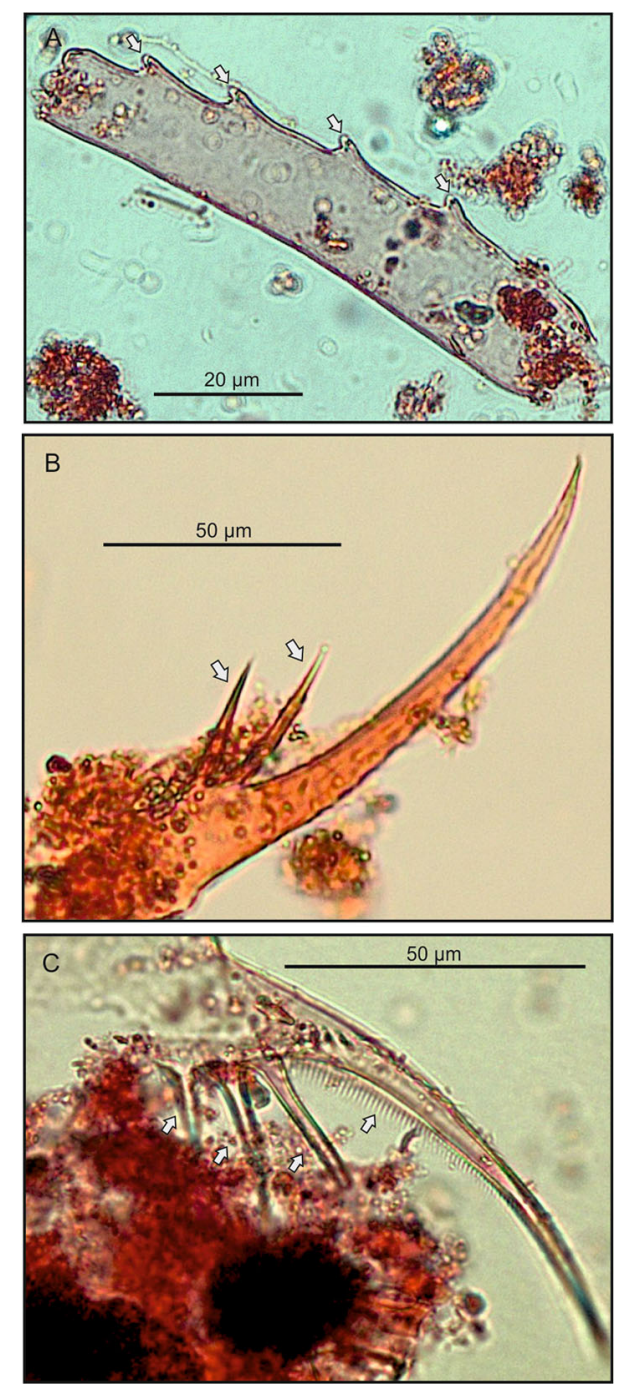

Fig. 2 Remains of Sididae: a exopodite segment, b postabdominal claw of Pseudosida bidentata, c postabdominal claw of Sarsilatona serricaudia of Sididae (Fig. 2a) is sporadically noted in the fossil record, and is characterized by the presence of 4-6 swimming hair articulations (tubercle-like appendages) on the margin.

Locality: Ticamaya

Genus Pseudosida Herrick, 1884.

Pseudosida bidentata Herrick, 1884.

\section{Large species.}

The post-abdominal claw (Fig. 2b) is usually slender, weakly curved, and approximately $0.1 \mathrm{~mm}$ in length with a narrow base, two long spines and a very short basal one (usually lost in subfossil remains). The length of the distal spine is less than one third the length of the claw. P. bidentata is a macrophyteassociated species that inhabits overgrown ponds and the littoral zone of lakes, and is found from the southern USA to Argentina (Korovchinsky 1992, 2004).

Locality: Verde

Genus Sarsilatona Korovchinsky, 1985.

Sarsilatona serricauda (Sars, 1901).

\section{Large species.}

The post-abdominal claw (Fig. 2c) is large in size (over $0.1 \mathrm{~mm}$ ) and strongly curved, with a very wide base and three long basal spines decreasing in length basally. The length of the distalmost spine is about half the length of the claw. Along the dorsal margin of the claw and behind the basal spines are rows of spinules (Fig. 2c) (Korovchinsky and Elías-Gutiérrez 2000). Sarsilatona serricauda is a benthic species that inhabits ponds, swamps, and shallow lakes; and is distributed from the southern USA to northern Argentina (Korovchinsky 1992, 2004; Korovchinsky and Elías-Gutiérrez 2000).

Locality: Ticamaya

Order Anomopoda Sars, 1865.

Family Bosminidae Baird, 1845.

Genus Bosmina Baird, 1845 sensu Sars, 1865.

Bosminidae are very often well preserved and common in lake sediment (Szeroczyńska and Sarmaja-Korjonen 2007). Their share in the cladoceran community is often dominant in paleolimnological studies (Korosi and Smol 2012a; Jeziorski et al. 2012). In lacustrine sediments, the valves and head shields of 
Bosminidae are commonly found, and both are very distinctive and easy to distinguish from other Cladocera families. Valves have a mucro (spine) on the posterior-ventral angle (Fig. 3a). The main characteristic feature of the head shield is two antennules attached to the rostrum (Fig. 3a). The surface sculpture includes reticulation and is usually visible on the head shields and valves in well-preserved remains.

The systematics of the genus Bosmina is quite problematic, and its "taxonomic instability is legendary" according to Kotov et al. (2009). The main reason is ontogenetic and seasonal variation of phenotypes (de Melo and Hebert 1994). Owing to this, the identification of Bosminidae subfossil remains to a species level is very difficult or near impossible. Therefore, it recommend in this paper to identify subfossil remains of Bosminidae into just two subgenera: Bosmina and Liederobosmina. The subgenus Bosmina encompasses three species: B. longirostris Müller, 1776; B. freyi, De Melo \& Hebert, 1994; and B. liederi De Melo \& Hebert, 1994, and all of them can be found in Central America. Liederobosmina is represented by six species in the Neotropic region: B. (L.) brehmi Lieder, 1962; B. (L.) chilensis Daday, 1902; B. (L.) hagmanni Stingelin, 1904; B. (L.) huaronensis Delachaux, 1918; B. (L.) macrostyla Daday, 1905; and B. (L.) tubicen Brehm, 1953 (Kotov et al. 2013). However, it appears that in the studied region, mainly $B$. (L.) huaronensis, B. (L.) tubicen and $B$. (L.) hagmanni occur.

subgenus Bosmina Baird, 1845.

Bosmina sp.

Small/medium-sized species.

The valves are arched (typically $B$. (B.) longirostris) or elongated (usually $B$. (B.) freyi and $B$. (B.) liederi), and are characterized by a vary mucro which can be relatively long or short (Fig. 3f). The mucro of Bosmina sp. is usually narrow and slightly curved at its midpoint. The distinctive trait of the mucro is the presence of ventral teeth (Fig. 3a, f1) (de Melo and Hebert 1994; Kotov et al. 2009). Unfortunately, this feature does not appear in all individuals, so it can be very difficult or near impossible to recognize Bosmina to the species level.

The characteristic feature that distinguishes the head shield of Bosmina from Liederobosmina is the different location of the lateral head pores. These pores in specimens of Bosmina are situated at the edge of the head shield (Figs. 3a, 4a, b). Head pores may be positioned extremely laterally, near the inflated edge in B. longirostris (as is shown in de Melo and Hebert 1994), or a small distance from the margin "between the rear branching of the forked lines of the fornix" in B.(B.) liederi and B. (B.) freyi (de Melo and Hebert 1994) (Fig. 4b). The lateral pores are rather small, elongated to elliptical, and sometimes difficult to observe. The sensory setae are situated between the base of the rostrum and the compound eye. Both the sensory setae and compound eye are not preserved after the organism's death. Therefore, the sensory setae are recorded in the subfossil remains as holes some distance from the base of the rostrum (Fig. 3a) (de Melo and Hebert 1994; Kotov et al. 2009). Unfortunately, this is not a diagnostic feature of Bosmina spp. Antennules are usually short and curved, but identification based on this trait is rather uncertain because the length can change in response to outside stress (e.g., predators).

This subgenus is represented in the Neotropics by three species: B. (B.) liederi, B. (B). freyi, and B. (B.) longirostris (Kotov et al. 2013). In Central American freshwater usually $B$. (B.) freyi and $B$. (B.) liederi represent the Bosmina subgenus. However, distinguishing these species from each other in the fossil record is near impossible due to a lack of diagnostic features.

Localities: Atitlán, Calderas, El Pino, Ipala, Salpetén, Yojoa, Apastapeque, El Espino

subgenus Liederobosmina Brtek, 1997.

Liederobosmina spp.

Large/medium-sized species.

The valves of Liederobosmina look similar to its sister group Eubosmina (absent in Central America). The valves of these two genera differ in the position of the mucro serrations. In Liederobosmina spp., mucro teeth are located on the dorsal side (Fig. 3a) (Paggi 1979; de Melo and Herbert 1994). The number of teeth vary, and their appearance can be smooth, or strongly marked incisions (Fig. 3g, g1) (Paggi 1979). The mucro differs in length and shape-in some specimens it is short and curved, but in others it is long and curved (Paggi 1979). For B. (L.) tubicen, the mucro is typically extremely long with well pronounced distal teeth. In specimens of $B$. (L.) hagmanni mucro teeth 

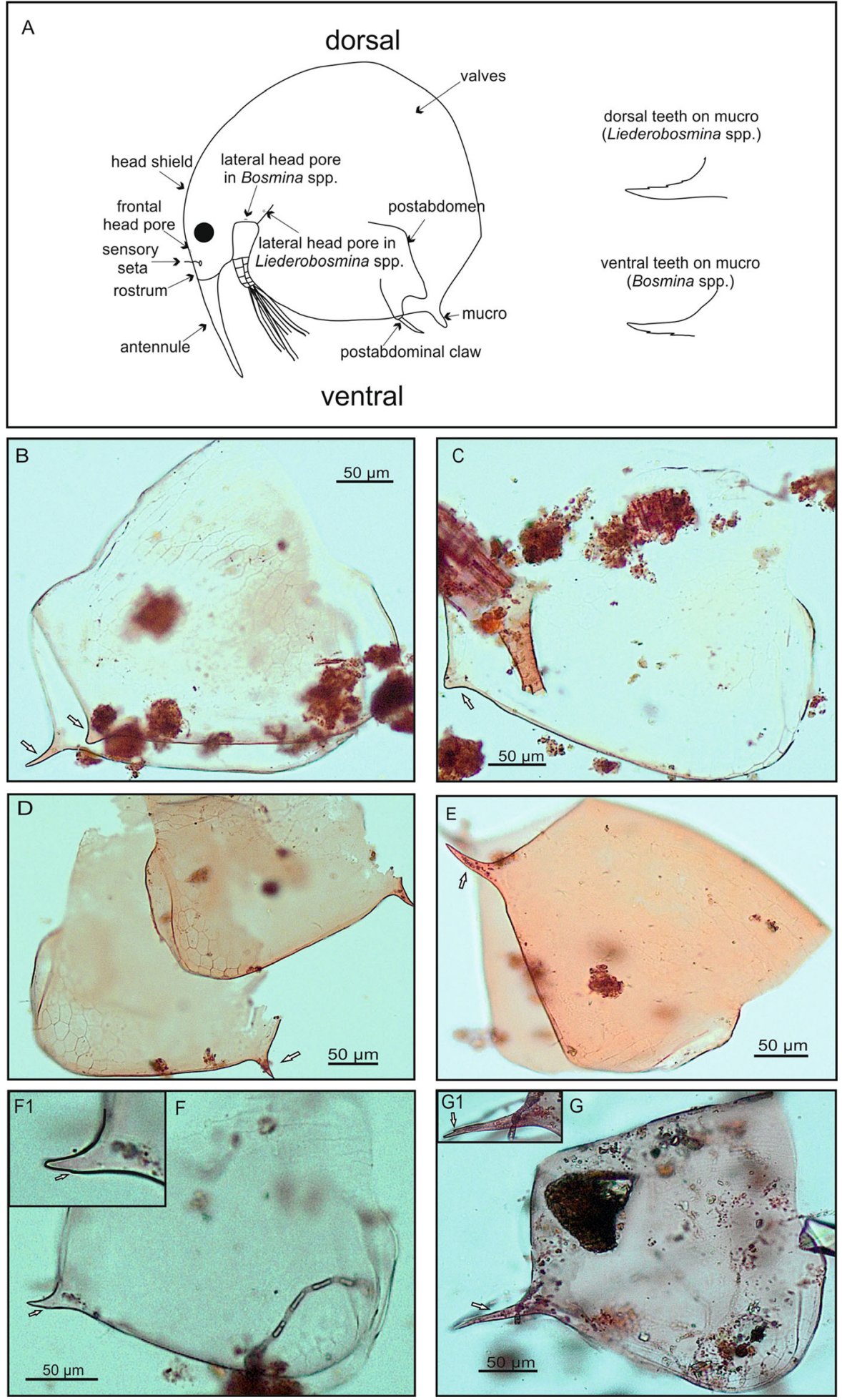

Fig. 3 Bosminidae: a general body structure characteristics for the Bosminidae species, $\mathbf{b}, \mathbf{c}, \mathbf{d}, \mathbf{e}$ different morphological types of valves belonging to Bosminidae, f valves of Bosmina spp.,

with the diagnostic ventral teeth on mucro (f1), $\mathbf{g}$ valves of Liederobosmina spp., with the characteristic dorsal teeth on mucro (g1) 

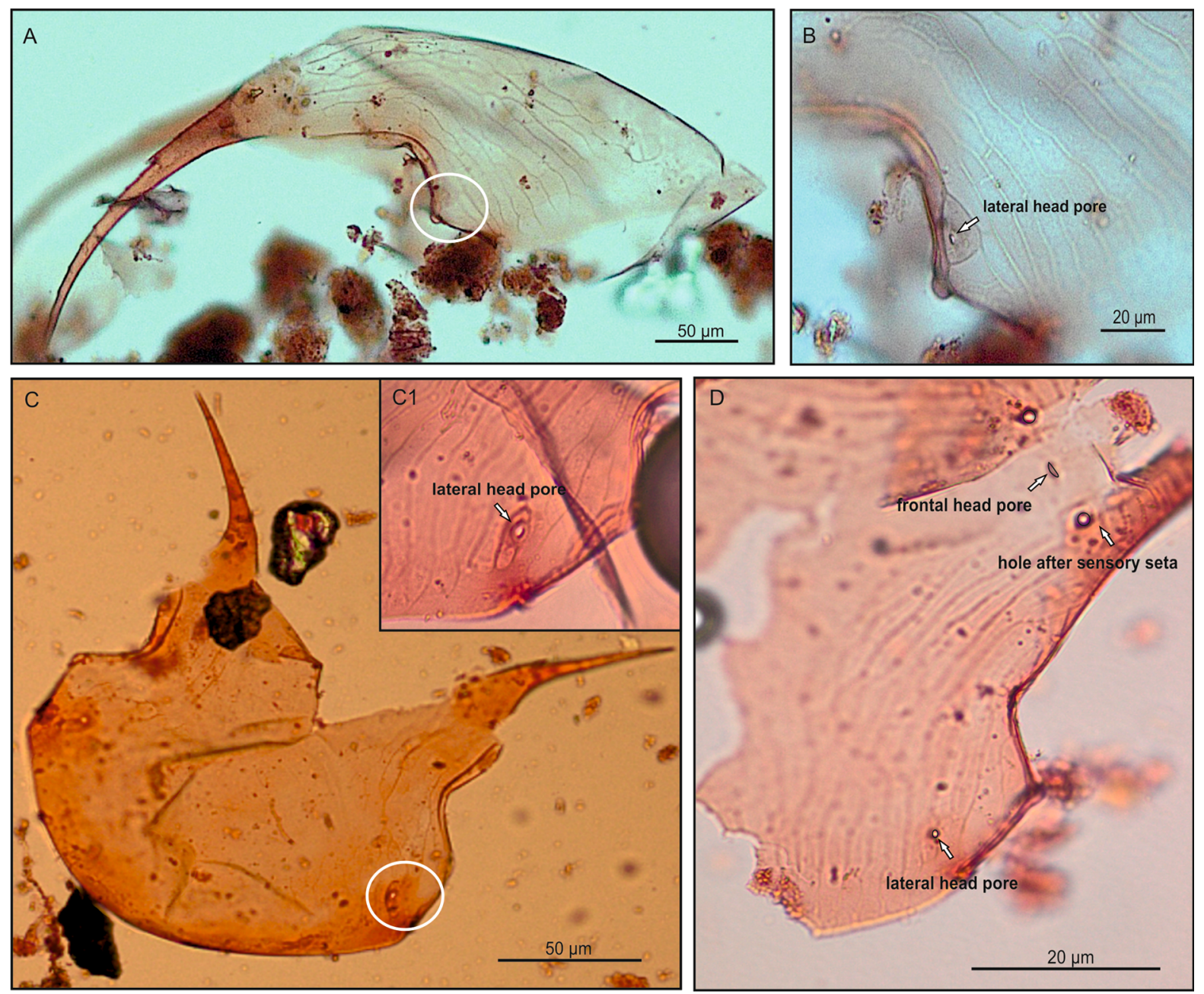

Fig. 4 Head shields of Bosminidae: a Bosmina spp., b lateral head pore in Bosmina spp., c Liederobosmina spp., d lateral head pore in Liederobosmina spp

are almost always observed-typically $2-3$ short and robust teeth (Paggi 1979). The base of the mucro in B. (L.) hagmanni and B. (L.) huaronensis is usually broad (de Melo and Herbert 1994). However, this feature varies between specimens and does not have a diagnostic function. The shape of valves varies from elongated and weakly curved to strongly arched. Therefore, identification of Liederobosmina valves to a species level is difficult due to the phenotypic plasticity of specimens from the Bosminidae family (Fig. 3b-g). The head shields of Liederobosmina are characterized by a short rostrum in $B$. (L.) hagmanni and $B$. (L.) tubicen and a long, blunt rostrum in specimens of B. (L.) huaronensis (Paggi 1979; de Melo and Herbert 1994). The resemblance of
Liederobosmina to Eubosmina is manifested in the position of the lateral head pore, which is located anterior to the mandibular articulation (Figs. 3a, 4c, d) (Paggi 1979). This feature distinguishes Liederobosmina from Bosmina. The lateral head pores are usually big, circular, and easy to observe. Sporadically, a frontal head pore may be observed. These incidences are the only case when $B$. (L.) huaronensis can be distinguished. The frontal pore of $B$. (L.) huaronensis is often flat and has a horseshoe shape, especially in adult specimens (Fig. 4d). This pore is occasionally circular in the juvenile specimens of $B$. (L.) huaronensis and rarely in adults (Paggi 1979). Sometimes, the holes after the sensory setae may be observed in the fossil head shield, which are situated at 
the base of the rostrum in all Liderobosmina species (Fig. 4d). Antennules have variable length.

Localities: Kaná, Emiliano Zapata, San Jose de la Montaña, La Perdida, Atitlán, El Rosario, Ipala, Camino de Lachua, Las Pozas, Sacnab, Salpetén, Quexil, Petexbatún, Yojoa, Apastapeque, Balamtetic

Family Daphniidae Straus, 1820.

Daphniidae remains are selectively preserved; therefore, they are usually underrepresented in the fossil record (Nykänen et al. 2009). The remains of Daphniidae mostly found in lacustrine sediments are the ephippium and post-abdominal claw. Filtering combs are also sometimes found. Recent research indicates that it is rare to find the head shield and shell of Daphniidae (Szeroczyńska and Zawisza 2005; Szeroczyńska and Sarmaja-Korjonen 2007).

One type of remains belonging to Daphniidae, which may be found in the sediments of Central American lakes is the post-abdominal claw. The most characteristic feature of the post-abdominal claw is the generally long and curved shape and short setae in the distal region (Fig. 5a). This claw is characterized by several stout spines in the proximal region (Fig. 5a). The number of spines vary. Unfortunately, this type of post-abdominal claw occurs in the species-complex of Daphnia pulex and Ceriodaphnia cf. reticulata (Berner 1986) as well. Therefore, it is difficult to assign this post-abdominal claw to a specific species. Additional evidence (for example a preserved ephippium; Vandekerkhove et al. 2004) is required to consider which genus or species-complex is represented in a sample. If additional evidence is lacking, it is recommend to assign this type of claw to the Daphniidae family.

Localities: Atitlán, Ipala, Coatapeque

Genus Ceriodaphnia Dana, 1853.

Ceriodaphnia sp.

Medium-sized species.

In two lakes, the ephippium of Ceriodaphnia was found. Its shape is semicircular. The dark egg chamber clearly distinguishes it from surrounding tissues (Fig. 5b) (Szeroczyńska and Sarmaja-Korjonen 2007; López-Blanco and Sinev 2016). It could be mistaken for Simocephalus sp. and Daphnia sp., but they have, respectively, a more elongated shape and two chambers (Szeroczyńska and Sarmaja-Korjonen 2007).

Localities: Chicabal, Chiligatoro

Genus Dapnia Müller, 1785.

Daphnia remains are selectively preserved. They are usually assigned to the species complexes of Daphnia pulex and Daphnia longispina (Szeroczyńska and Sarmaja-Korjonen 2007; Korosi and Smol 2012a) based on the presence of the postabdominal claw and ephippium. This is especially true for European lake sediments. In the tropics, the situation is different, and while the species complex $D$. pulex usually cannot be confidently recognized, D. longispina species complex is represented in the region by just one species (Daphnia laevis), thus their post-abdominal claw can be used to identify it at the species level.

In the Neotropics, Daphnia species are rare and were noted only in highland waterbodies in the fossil record (Wojewódka et al. 2016).

Daphnia laevis Birge, 1878.

Large/medium-sized species.

The post-abdominal claw is curved and tapered towards the distal end. Daphnia laevis have short setae that are located close to each other (Elías-Gutiérrez et al. 2008), and increase in size towards the claw articulation (Fig. 5c). Sometimes, the distalmost part of the post-abdomen is preserved and attached to the claw. There are long, arched denticles (lacking in the specimens from Fig. 5c).

Localities: Atitlán, Chicabal, El Pino, Ipala, Magdalena, Chiligatoro, Yojoa, Verde

Family Macrothricidae Norman \& Brand, 1867 emend Smirnov, 1992.

Genus Macrothrix Baird, 1843.

Macrothrix elegans Sars, 1901.

\section{Large species.}

The post-abdomen of Macrothrix spp. is distinctive due to a markedly rounded dorsal margin with distally diminishing setules (Fig. 5d) that are more robust in the distal portion (Kotov et al. 2004). The distal embayment is weakly pronounced (Fig. 5d). The preanal and postanal angles are not pronounced. Other remains were not found in the studied surface 

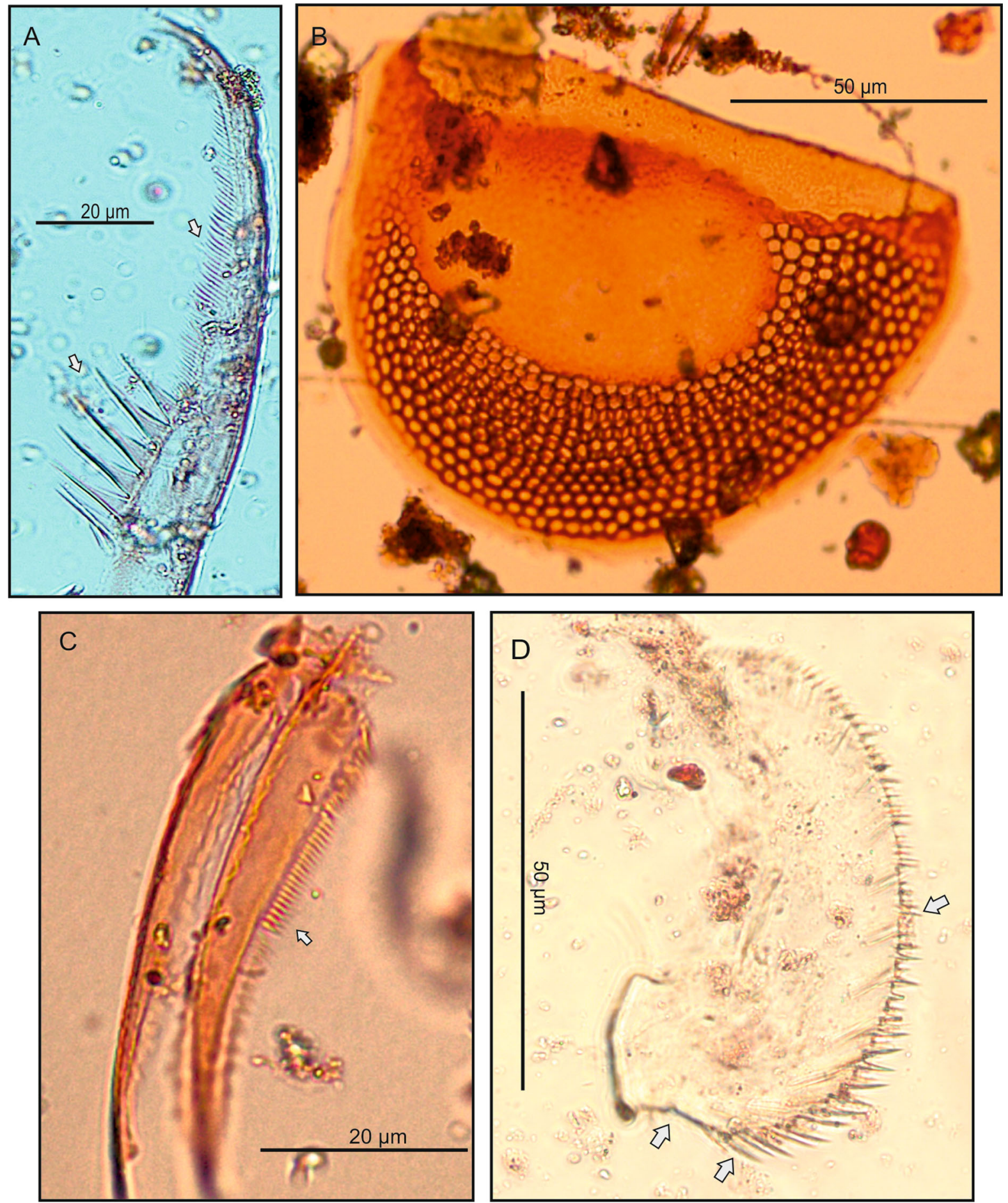

Fig. 5 a Postabdominal claw characteristics for Daphnia pulex-group and Ceriodaphnia cf. reticulata, b ephippium of Ceriodaphnia sp., c postabominal claw of Daphnia laevis, $\mathbf{d}$ postabdomen of Macrothrix elegans 
sediments. The full description of the body of M. elegans is given in Kotov et al. (2004).

Macrothrix mainly encompasses mud dwellers. This genus in the Neotropical region is represented by M. elegans which, in turn, is often the predominant anomopod in ponds and puddles (Kotov et al. 2004). However, it seems that this genus is weakly represented in the fossil record and their remains are rarely found.

Locality: Ticamaya

Genus Grimaldina Richard, 1892.

Grimaldina freyi Neretina \& Kotov, 2017

\section{Large species.}

Only a portion of a valve of Grimaldina freyi were found. Despite this, recognition of this species was possible due to the characteristic features of the carapace. Valves (Fig. 6) are covered in a characteristic sculpturing resembling fish scales (Fig. 6a1, b), and bear a row of distinctive spines on the posteriorventral angle (Fig. 6a, b) (Hollwedel et al. 2003;
Neretina and Kotov 2017). However, it appears that the preservation of remains from this species is poor, and they are therefore rare in the fossil record. This species is found in small puddles, swampy areas, and the densely vegetated littoral zone of lakes (Neretina and Kotov 2017). Historically, records of Grimaldina from America were attributed to G. brazzai Richard, 1892, and presumed to be pan-tropical (Hollwedel et al. 2003). Recent revision (Neretina and Kotov 2017) revealed that G. brazzai is a Paleo-tropical species, while the Neotropical region is inhabited by G. freyi.

\section{Locality: Ticamaya}

Family Ilyocryptidae Smirnov, 1971.

Genus Ilyocryptus Sars, 1861.

Ilyocryptus spinifer Herrick, 1882.

\section{Large species.}

The posterior-dorsal angle of valves is arched. The dorsal portion has a well-pronounced keel. The valves are completely covered by hexagonal reticulation

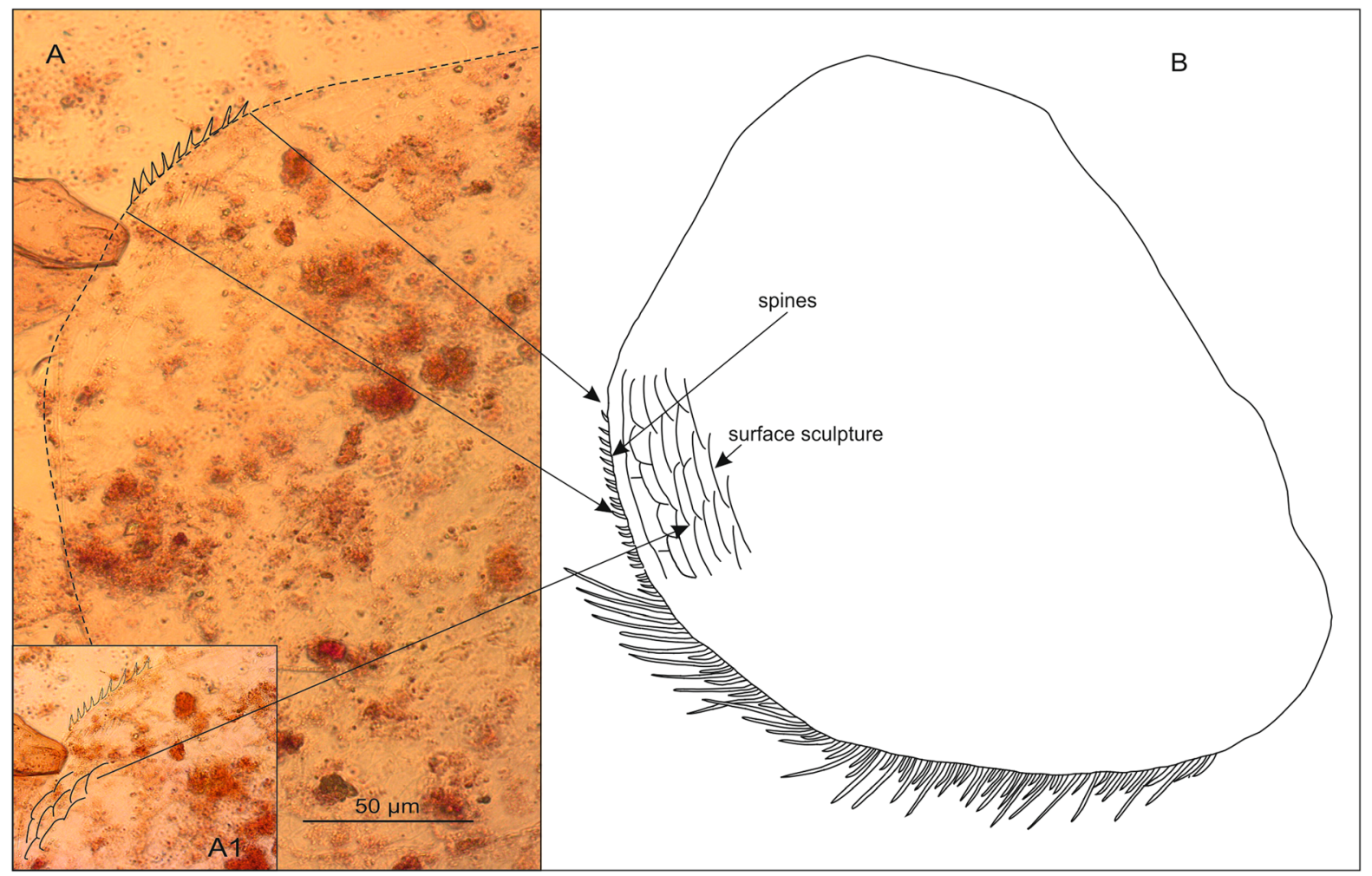

Fig. 6 a A portion of valves of Grimaldina freyi. Due to the unclear picture (poor preservation of remains, thin chitin) the margin of the valves and spines are marked by a dotted line and a smooth line, respectively, a1 posterior-ventral angle with characteristic spines and surface sculpture, b general valves structure characteristic for $G$. freyi 


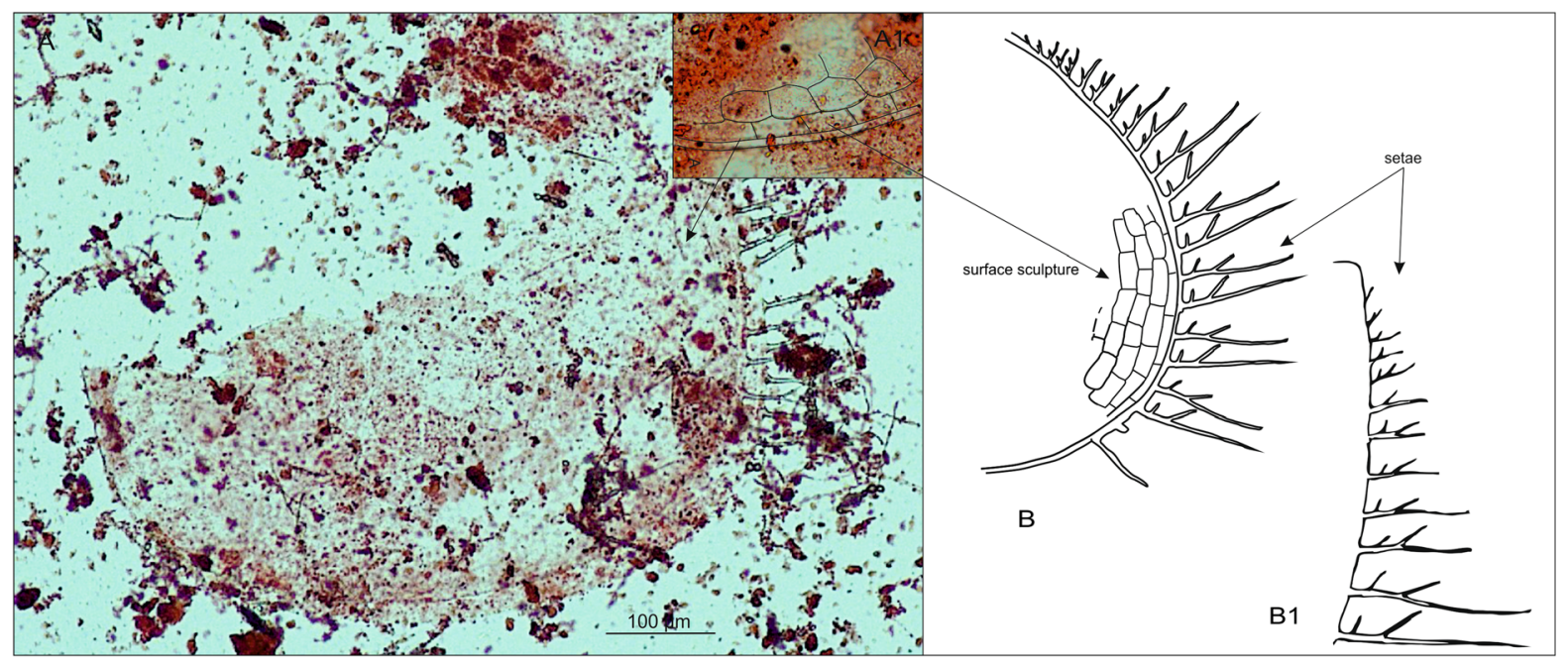

Fig. 7 a Valves margin of Ilyocryptus spinifer, a1 surface structure, b general structure of the valves margin characteristic for $I$. spinifer, b1 general shape of setae with distinctive spine stout characteristic for I. spinifer

(Fig. 7a1, b) (Kotov and Dumont 2000). The most distinctive feature is the presence of marginal setae (48-64) along the valve margin (Fig. 6a, b, b1) (Kotov and Dumont 2000). These have different sizes and appearances. Most of them are detached in the fossils. However, the presence of setae on the posterior margin distinguishes the remains of $I$. spinifer from other Ilyocryptus species. These setae are characterized by a spine stout (Fig. 6b1) that is typically well preserved.

In the fossil record, only this very distinctive portion of valve margin is found. A description of the whole body may be found in Kotov and Dumont (2000). The remains of Ilyocryptus spp. are otherwise rare. Species from this group are mostly benthic and associated with the muddy bottoms of lakes.

Locality: Balamtetic

\section{Discussion}

Over the last two decades, taxonomical Cladocera studies in Central America have been developing rapidly (e.g., Ciros-Pérez and Elías-Gutiérrez 1997; Elías-Gutiérrez and Suárez-Morales 1999; ElíasGutiérrez et al. 1999, 2001, 2006; Kotov et al. 2001, 2005; Garfias-Espejo and Elías-Gutiérrez 2004; Kotov et al. 2004). However, most of these studies concentrated on a few regions located in Mexico. Hence, there is still a lot of uncertainty and lack of knowledge about Cladocera taxonomy and populations in Central America. Furthermore, studies of Cladocera fossils are even more rare (Zawisza et al. 2012, 2014, 2017; Szeroczyńska et al. 2015; Wojewódka et al. 2016). Subfossil Cladocera analysis in Central America is complicated because well-established taxonomy are crucial for accurately identifying remains.

Presently, many Cladocera species from the American tropics need to be redescribed. Previous taxonomical descriptions were often insufficient, and led to continual misidentification. This problematic taxonomical knowledge is probably one of the reasons that limited paleolimnological investigations in Central America relied on Cladocera remains. This problem seems to be even more complicated because the European names for Neotropical taxa have been incorrectly adapted due to the external similarities between them (e.g., Eubosmina and Liederobosmina).

Consistent efforts to extend knowledge about the taxonomy and biodiversity of Cladocera in the northern Neotropics and the morphological characteristics of their subfossil remains will enable further research of the fossil records. Thus, in the future, we expect an increase in research that will provide new data, and will thus upgrade the old data. Any study that aims to do this should analyze living organisms (limnological studies) in parallel with subfossil remains (paleolimnological studies). This integrated approach could help to reduce potential taxonomic uncertainties. 
This paper, together with a paper focusing on chydorid species (Wojewódka et al. 2020), is the first step in filling the existing gap in the study of Cladocera fossils in the northern Neotropics. The description of the remains of 10 taxa, including planktonic and benthic taxa, in this paper is one of the first steps in extending knowledge about non-chydorid species known from Central America.

The planktonic families Bosminidae and Daphniidae often constitute the dominant group in Cladocera assemblages wherein the occurrence of Daphniidae seems to be limited to highland waterbodies (Peréz et al. 2013; Wojewódka et al. 2016). Those families also often play a key role in the aquatic ecosystem, and it is essential to provide uniform guidelines for their identification. However, it is important to mention that species-level classification of Bosminidae remains is very problematic due to extensive phenotypic plasticity (Korosi et al. 2013). Morphological variability within species has been proven with numerous studies, and this is particularly true for body size, lengths of antennules and shapes of valves and mucros, which change in response to predation pressure (Kerfoot 1975a, 2006; Korosi et al. 2013) or some abiotic factors like temperature, turbulence (Kerfoot 1975b) and tropic state (Hann et al. 1994). Therefore, identification of Bosminidae to a species level based on their remains can be difficult. Considering this, we recommend identifying Bosminidae just to a subgenus level (Bosmina and Liederobosmina).

The remains of Daphniidae in sediments are usually the post-abdominal claw and ephippium (Korhola and Rautio 2001). These body parts of Daphniidae were found in neotropical lakes where only three taxa were observed: Daphnia laevis, Daphnia pulex speciescomplex and Ceriodaphnia sp. In the waters of the south Mexican lakes, Elías-Gutiérrez (2006) reported 36 Daphniidae species belonging to four genera (Simocephalus, Ceriodaphnia, Scapholeberis, and Daphnia). The reasons for the very limited number of recorded taxa in sediments likely is because (1) selective and rather weak preservation of remains due to their fragility, (2) the rarity of those taxa and therefore difficulty in finding their remains, and (3) difficulties connected with taxonomic identification.

Furthermore, in the sediments of Neotropical lakes, it was also noted that other non-chydorid taxa, socalled "large Cladocera", was limited in diversity. Bentic Macrothricidae and Illocryptidae were represented only by one species each-Macrothrix elegans and Illocryptus spinifer, respectively. Pseudosida bidentata, Sarsilatona serricauda, and Grimaldina freyi were also found very rarely.

Acknowledgements The study was funded by the National Science Center, Poland (Grant Nos. 2014/13/B/ST10/02534 and 2012/05/B/ST10/00469) and Institute of Geological Sciences, Polish Academy of Sciences (internal grant for young researchers). Research was also supported by the Program Pioneers into Practice Climate-KIC (grant to Marta Wojewódka). We thank the editors, A.A.Kotov and one anonymous reviewer who significantly improved the manuscript with their comments on the original manuscript. We are very grateful to Dr. Ashley Gumsley (University of Silesia) who helped us with the English version of the paper and provided comments. We thank Sergio Cohuo, Laura MacarioGonzález, Liseth Pérez, Antje Schwalb (Technische Universität Braunschweig), Margarita Caballero (Universidad Nacional Autónoma de México) for providing sediment samples. Special thanks to Cuauhtémoc Ruiz (Instituto Tecnológico de Chetumal), Ramón Beltrán (Centro Interdisciplinario de Ciencias Marinas, Mexico), and Lisa Heise (Universidad Autónoma de San Luis Potosí, Mexico) for their excellent work on the field trips. We would also like to thank all people involved in this work: Alexis Oliva and the team from the Asociación de Municipios del Lago de Yojoa y su área de influencia (AMUPROLAGO, Honduras), María Reneé Alvarez, Margarita Palmieri, Eleonor de Tott (Universidad del Valle de Guatemala, Guatemala), Consejo Nacional de Áreas Protegidas (CONAP, Guatemala), Néstor Herrera and Ministerio de Medio Ambiente (San Salvador, El Salvador).

Open Access This article is licensed under a Creative Commons Attribution 4.0 International License, which permits use, sharing, adaptation, distribution and reproduction in any medium or format, as long as you give appropriate credit to the original author(s) and the source, provide a link to the Creative Commons licence, and indicate if changes were made. The images or other third party material in this article are included in the article's Creative Commons licence, unless indicated otherwise in a credit line to the material. If material is not included in the article's Creative Commons licence and your intended use is not permitted by statutory regulation or exceeds the permitted use, you will need to obtain permission directly from the copyright holder. To view a copy of this licence, visit http://creativecommons.org/licenses/by/4.0/.

\section{References}

Berner DB (1986) Taxonomy of Ceriodaphnia (Crustacea: Cladocera) in U.S. Environmental Protection Agency Cultures, Cincinnati, USA

Ciros-Pérez J, Elías-Gutiérrez M (1997) Macrothrix smirnovi, a new species (Crustacea: Anomopoda: Macrothricidae) 
from Mexico, a member of the M. triserialis-group. Proc Biol Soc Wash 110:115-127

Cohuo S, Macario-Gonzáleza L, Pérez L, Schwalb A (2016) Overview of Neotropical-Caribbean freshwater ostracode fauna (Crustacea, Ostracoda): identifying areas of endemism and assessing biogeographical affinities. Hydrobiologia 786:5-21

Correa-Metrio A, Bush MB, Pérez L, Schwalb A, Cabrera KR (2011) Pollen distribution along climatic and biogeographic gradients in northern Central America. The Holocene 21:681-692

Cuna E, Zawisza E, Caballero M, Ruiz-Fernández AC, LozanoGarcía S, Alcocer J (2014) Environmental impacts of Little Ice Age cooling in central Mexico recorded in the sediments of a tropical alpine lake. J Paleolimnol 51:1-14

Curtis JH, Brenner M, Hodell DA, Balser RA, Islebe GA, Hooghiemstra H (1998) A multi-proxy study of Holocene environmental change in the Maya Lowlands of Peten, Guatemala. J Paleolimnol 19:139-159

de Melo R, Hebert R (1994) A taxonomic reevaluation of North American Bosminidae. Can J Zool 72:1808-1825

Diaz K, Pérez L, Correa-Metrio A, Franco-Gaviria JF, Echeverría P, Curtis J, Brenner M (2017) Holocene environmental history of tropical, mid-altitude Lake Ocotalito, México, inferred from ostracodes and non-biological indicators. The Holocene 27:1-10

Elías-Gutiérrez M, Suárez-Morales E (1999) Alona pectinata (Crustacea: Anomopoda; Chydoridae), a new freshwater cladoceran from Southeast Mexico. Rev Biol Trop 47:105-111

Elías-Gutiérrez M, Ciros-Péres J, Suárez-Morales E, SilvaBriano M (1999) The freshwater Cladocera (orders Ctenopoda and Anomopoda) of Mexico, with comments on selected taxa. Crustaceana 72:171-186

Elías-Gutiérrez M, Smirnov NN, Suárez-Morales E, DimasFlores N (2001) New and little known cladocerans (Crustacea: Anomopoda) from southeastern Mexico. Hydrobiologia 442:41-54

Elías-Gutiérrez M, Kotov AA, Garfias-Espejo T (2006) Cladocera (Crustacea: Ctenopoda, Anomopoda) from southern Mexico, Belize and northern Guatemala, with some biogeographical notes. Zootaxa 1119:1-27

Elías-Gutiérrez M, Suárez-Morales E, Gutiérrez-Aguirre MA, Silva-Briano M, Granados-Ramírez JG, Garfias-Espejo T (2008) Cladocera y Copepoda de las aguas continentales de México. Universidad Nacional Autónoma de México, México

Escobar J, Hodell DA, Brenner M, Curtis JH, Gilli A, Mueller AD, Anselmetti FS, Ariztegui D, Grzesik DA, Pérez L, Schwalb A, Guilderson TP (2012) A 43- ka record of paleoenvironmental change in the Central American lowlands inferred from stable isotopes of lacustrine ostracods. Quat Sci Rev 37:92-104

Flössner D (2000) Die Haplopoda und Cladocera (ohne Bosminidae) Mitteleuropas. Backhuys Publishers, Leiden

Franco-Gaviria F, Caballero-Rodriguez D, Correa-Metrio A, Pérez L, Schwalb A, Cohuo S, Macario-Gonzáleza L (2018a) The human impact imprint on modern pollen spectra of the Maya lands. Bol Soc Geol Mex 70:61-78

Franco-Gaviria F, Correa-Metrio A, Cordero-Oviedo C, LópesPérez M, Cárdenes-Sandí GM, Romero FM (2018b)
Effects of late Holocene climate variability and anthropogenic stressors on the vegetation of the Maya highlands. Quat Sci Rev 189:76-90

Frey DG (1986) Cladocera analysis. In: Berglund BE (ed) Handbook of Holocene palaeoecology and palaeohydrology. Wiley, Chichester, pp 667-692

Garfias-Espejo T, Elías-Gutiérrez M (2004) Taxonomy and distribution of Macrothricidae (Crustacea: Anomopoda) in southeastern Mexico, northern Guatemala and Belize. An Inst Biol Univ Nac Auton Mex Ser Zool 74:105-134

Hamerlik L, Wojewódka M, Zawisza E, Cohuo Duran S, Macario-Gonzáleza L, Pérez L, Szeroczyńska K (2018) Subfossil Chironomidae (Diptera) in surface sediments of the sinkholes (cenotes) of the Yucatan Peninsula: diversity and distribution. J Limnol 77:213-219

Hann BJ, Leavitt PR, Chang PSS (1994) Cladocera community response to experimental eutrophication in Lake 227 as recorded in laminated sediments. Can J Fish Aquat Sci 51:2312-2321

Hollwedel W, Kotov AA, Brandorff GO (2003) Cladocera (Crustacea: Brachiopoda) from the Pantanal (Brazil). Arthropoda Sel 12:67-93

Jeziorski A, Paterson AM, Smol JP (2012) Crustacean zooplankton sedimentary remains from calcium-poor lakes: complex responses to threshold concentrations. Aquat Sci 74:121-131

Kerfoot WC (1975a) The divergence of adjacent populations. Ecology 56:1298-1313

Kerfoot WC (1975b) Seasonal changes of Bosmina (Crustacea, Cladocera) in Frains Lake, Michigan: laboratory observations of phenotypic changes induced by inorganic factors. Freshw Biol 5:227-243

Kerfoot WC (2006) The Baltic Eubosmina radiation: sensitivity to invertebrate predators (induction) and observations on genetic differences. Arch Hydrobiol 167:147-168

Korhola A, Rautio M (2001) Cladocera and other Branchiopod crustaceans. In: Smol JP, Birks JB, Last WM (eds) Tracking environmental change using lake sediments, zoological indicators. Kluwer, Dordrecht, pp 5-41

Korosi JB, Smol JP (2012a) An illustrated guide to the identification of cladoceran subfossils from lake sediments in northeastern North America: part 1-the Daphnidae, Leptodoridae, Bosminidae, Polyphemidae, Holopedidae, Sididae and Macrothricidae. J Paleolimnol 48:571-586

Korosi JB, Smol JP (2012b) An illustrated guide to the identification of cladoceran subfossils from lake sediments in northeastern North America: part 2-the Chydoridae. J Paleolimnol 48:587-622

Korosi JB, Kurek J, Smol JP (2013) A review on utilizing Bosmina size structure archived in lake sediments to infer historic shifts in predation regimes. J Plankton Res 35(2):444-460

Korovchinsky NM (1992) Guide to the Identification of the Microinverterbrates of the Continental Waters of the World 3. Sididae \& Holopediidae (Crustacea: Daphniiformes). SPB Academic Publishing, The Hague

Korovchinsky NM (2004) Cladocerans of the order Ctenopoda of the world fauna (morphology, systematics, ecology, biogeography). KMK Press, Moscow, p 410 (in Russian)

Korovchinsky NM, Elías-Gutiérrez M (2000) First record of Sarsilationa serricauda (Sars, 1901) (Crustacea: 
Branchiopoda: Sididae) from Mexico, with redescription of its male. Arthropoda Sel 9:5-11

Kotov AA, Dumont HJ (2000) Analysis of the Ilyocryptus spinifer-species group (Anomopoda, Brachiopoda), with description of a new species. Hydrobiologia 428:83-113

Kotov AA, Elías-Gutiérrez M, Gutiérrez-Aguirre M (2001) Ilyocryptus paranaensis inarmatus subsp nov from Tabasco, Mexico (Cladocera. Anomopoda). Crustaceana 74:1067-1082

Kotov AA, Garfias-Espejo T, Ellas-Gutiérrez M (2004) Separation of two Neotropical species: Macrothrix superaculeata (Smirnov, 1982) versus M. elegans Sars, 1901 (Macrothricidae, Anomopoda, Cladocera). Hydrobiologia 517:61-88

Kotov AA, Elías-Gutiérrez M, Granados-Ramirez JG (2005) Moina dumonti sp. nov. (Cladocera, Anomopoda, Moinidae) from southern Mexico and Cuba, with comments on moinid limbs. Crustaceana 78:41-57

Kotov AA, Ishida S, Taylor DJ (2009) Revision of the genus Bosmina Baird, 1845 (Cladocera: Bosminidae), based on evidence from male morphological characters and molecular phylogenies. Zool J Linn Soc 156:1-51

Kotov AA, Forró L, Korovchinsky NM, Petrusek A (2013) World checklist of freshwater Cladocera species in the catalogue of life. World Wide Web Electronic Publication

López-Blanco C, Sinev AY (2016) Cladocera in La Tembladera Lake, Ecuador. Crustaceana 89:1611-1637

Macario-Gonzáleza L, Cohuo S, Elías-Gutiérrez M, Vences M, Pérez L, Schwalb A (2018) Integrative taxonomy of freshwater ostracodes (Crustacea: Ostracoda) of the Yucatán Peninsula, implications for paleoenvironmental reconstructions in the northern Neotropical region. Zool Anz 275:20-36

Neretina AA, Kotov AA (2017) Old World-New World differentiation of so-called "circumtropical" taxa: the case of rare genus Grimaldina Richard, 1892 (Branchiopoda: Cladocera: Macrothricidae). Zootaxa 4291:295-323

Nykänen M, Vakkilainen K, Liukkonen M, Kairesalo T (2009) Cladoceran remains in lake sediments: a comparison between plankton counts and sediment records. J Paleolimnol 42:551-570

Paggi JC (1979) Revision de las especies argentinas del genero Bosmina Baird agrupadas en el subgenero Neobosmina Lieder (Cruastcea: Cladocera). Acta Zool Lilloana XXXV:137-162

Pérez L, Bugja R, Lorenschat J, Brenner M, Curtis J, Hoelzmann P, Islebe G, Scharf B, Schwalb A (2011) Aquatic ecosystems of the Yucatan Peninsula (Mexico), Belize, and Guatemala. Hydrobiologia 661:407-433

Pérez L, Lorenschat J, Massaferro J, Pailles Ch, Sylvestre F, Hollwedel W, Brandorff GO, Brenner M, Islebe G, Lozano MS, Scharf B, Schwalb A (2013) Bioindicators of climate and trophic state in lowland and highland aquatic ecosystems of the Northern Neotropics. Rev Biol Trop 61:603-644

Sigal I, Caballero M, Correa-Metrio A, Lozano-García S, Vázquez G, Pérez L, Zawisza E (2017) Basic limnology of
30 continental waterbodies of the Transmexican Volcanic Belt across climatic and environmental gradients. Bol Soc Geol Mex 69:313-370

Sinev AY, Silva-Briano M (2012) Cladocerans of genus Alona Baird, 1843 (Cladocera: Anomopoda: Chydoridae) and related genera from Aguascalientes State, Mexico. Zootaxa 3569:1-24

Sinev AY, Zawisza E (2013) Comments on cladocerans of crater lakes of the Nevado de Toluca Volcano (Central Mexico), with the description of a new species Alona manueli sp. Nov Zootaxa 3647:390-400

Sweetman JN, Smol JP (2006) A guide to the identification of cladoceran remains (Crustacea, Branchiopoda) in Alaskan lake sediments. Arch Hydrobiol Suppl 151/4, Monogr Stud 353-394

Szeroczyńska K, Sarmaja-Korjonen K (2007) Atlas of Subfossil Cladocera from Central and Northern Europe. Friends of the Lower Vistula Society

Szeroczyńska K, Zawisza E (2005) Daphnia remains from the sediment of Lake Somaslampi (NW Finish Lapland) and Lake Wigry (NE Poland). Stud Quat 22:55-57

Szeroczyńska K, Zawisza E, Wojewódka M (2015) Initial time of two high altitude crater lakes (Nevado De Toluca, Central Mexico) recorded in subfossil Cladocera. Stud Quat 32:109-116

Vandekerkhove J, Declerck S, van Hove M, Brendonck L, Jeppesen E, Conde Porcuna JM, De Meester L (2004) Use of ephippial morphology to assess richness of anomopods: potentials and pitfalls. J Limnol 63:75-84

Wojewódka M, Zawisza E, Cohuo S, Macario-González L, Schwalb A, Zawiska I, Pérez L (2016) Ecology of Cladocera species from Central America based on subfossil assemblages. Adv Oceanogr Limnol 7:151-152

Wojewódka M, Sinev AY, Zawisza E, Stańczak J (2020) A guide to the identification of subfossil chydorid Cladocera (Crustacea: Branchiopoda) from lake sediments of Central America and the Yucatan Peninsula, Mexico: part II. J Paleolimnol 63:37-64

Zawisza E, Caballero M, Ruiz-Fernandez C (2012) 500 years of ecological changes recorded in subfossil Cladocera in a high-altitude tropical lake Lago de La Luna, Central Mexico. Stud Quat 29:23-29

Zawisza E, Correa-Metrio A, Caballero M, Lozano S, Szeroczyńska K (2014) Paleoecology of tropical Lake Zirhauen (Western Mexico) recorded in Cladocera remains. In: 8th shallow lakes conference, 12-17 Oct 2014, Antalya, Turkey

Zawisza E, Cuna E, Caballero M, Ruiz-Fernandez AC, Szeroczyńska K, Woszczyk M, Zawiska I (2017) Environmental changes during the last millennium recorded in subfossil Cladocera, diatoms and sediment geochemistry from Lake El Sol (Central Mexico). Geol Q 61:81-90

Publisher's Note Springer Nature remains neutral with regard to jurisdictional claims in published maps and institutional affiliations. 